\title{
Keterampilan mahasiswa dalam melakukan penelitian pendidikan matematika melalui pembelajaran berbasis riset
}

\author{
Rully Charitas Indra Prahmana ${ }^{1}$, Yaya S. Kusumah, Darhim²
}

\begin{abstract}
Abstrak: Penelitian ini bertujuan untuk mengungkap kecenderungan lintasan belajar mahasiswa dalam melakukan penelitian pendidikan matematika, khususnya dalam kemampuan mendesain, melaksanakan, dan mempublikasikan hasil penelitian, dengan menggunakan model pembelajaran berbasis riset. Metode yang digunakan adalah design research dengan 3 tahapan, yaitu preliminary design, teaching experiment, dan retrospective analysis. Penelitian ini mendeskripsikan bagaimana lintasan belajar yang dikembangkan memberikan kontribusi dalam menumbuhkan keterampilan meneliti pada 9 mahasiswa pendidikan matematika di STKIP Surya, dengan mendeskripsikan kegiatan dosen, mahasiswa, dan melihat hasil akhir pembelajaran, selama kurun waktu 5 bulan. Hasilnya, 2 orang mahasiswa mampu memenuhi semua indikator keterampilan meneliti sampai tahapan publikasi karya ilmiah dalam jurnal yang terindeks Google Scholar, 1 orang mahasiswa sampai tahapan penulisan hasil penelitian (skripsi), 2 orang mahasiswa sampai tahapan pembuatan proposal penelitian dan sudah diseminarkan, 3 orang mahasiswa sampai tahapan pembuatan proposal penelitian, dan 1 orang mahasiswa masih dalam tahapan mendesain suatu penelitian. Selain itu, penelitian ini juga memberikan gambaran faktor-faktor penyebab keberagaman hasil yang diperoleh mahasiswa selama proses pembelajaran.
\end{abstract}

Kata kunci: Pembelajaran Berbasis Riset; Keterampilan Meneliti; Penelitian Pendidikan Matematika; Design Research

\begin{abstract}
This study aims to reveal the tendency of students' learning trajectory in doing research in mathematics education, especially in the ability to design, implement, and publish the research result by using research-based learning model. The method used is design research with three phases, i.e., preliminary design, teaching experiment, and retrospective analysis. This study describes how the learning trajectory that was developed to contribute to enhancing the research skills of nine pre-service mathematics' teacher at Surya College of Education with describing the activities of lecturer, students, and the final result of learning during five months. As a result, two students were able to
\end{abstract}

\footnotetext{
${ }^{1}$ Surya College of Education, Tangerang, Indonesia, rully.charitas@stkipsurya.ac.id

2 Universitas Pendidikan Indonesia, Bandung, Indonesia
} 
meet all the indicators of research's skill until publishing a scientific paper in journals indexed by Google Scholar. One student was able to the stage of writing the research result (undergraduate thesis). Two students were able to the stage of making a research proposal and already seminar. Three students were able to the stage of making a research proposal. One student is still in the stage of research design. Besides, this study also illustrates the diversity of the factors that cause results obtained by students during the learning process.

Keywords: Research-Based Learnin; Research's Skill; Research in Mathematics Educatio; Design Research

\section{A. Pendahuluan}

Kesulitan mahasiswa dalam menyelesaikan skripsi yang berakibat pada lamanya masa studi telah menjadi objek penelitian selama lebih dari 1 dekade terakhir (Fathonah, Wahyuningsih, \& Wahyuningsih, 2011; Santosa, Wiyanarti, \& Darmawan, 2009; Bangun, Irmeilyana, \& Andarini, 2011; Firmansyah, 2014; Prahmana, 2014). Lemahnya pengetahuan metodologi penelitian mahasiswa (Firmansyah, 2014), peran dosen pembimbing, dan minimnya keterlibatan mahasiswa dalam penelitian dosen, menjadi beberapa faktor penyebab kesulitan mahasiswa dalam menyelesaikan skripsi (Fathonah dkk, 2011). Selain itu, mahasiswa juga dituntut memiliki keterampilan menulis karya ilmiah, agar penulisan skripsi berjalan lebih mudah (Puspitasari, 2013; Prahmana, 2015a). Kesulitan-kesulitan ini terkait dengan minimnya pengalaman mahasiswa dalam melakukan penelitian, menulis karya ilmiah, dan publikasi karya ilmiah selama masa perkuliahan (Prahmana, 2015b). Oleh karena itu, pengalaman meneliti menjadi suatu hal yang penting bagi mahasiswa sebelum mengambil mata kuliah skripsi.

Penelitian merupakan suatu kegiatan yang sistematis dan objektif untuk mencari kebenaran dan memecahkan atau menjawab suatu permasalahan (Siswono, 2010). Keinginan untuk mengetahui sesuatu, atau keingintahuan tentang suatu hal, bagaimana sesuatu tersebut, dan apa yang sesuatu itu lakukan atau akan lakukan menjadi motivasi tersendiri dalam melaksanakan suatu kegiatan penelitian (Willison \& O'Regan, 2007). Di sisi lain, mahasiswa dituntut harus mampu melakukan penelitian dan menghasilkan karya tulis ilmiah (skripsi) sebagai bagian dari kompetensi lulusan suatu perguruan tinggi (Tim Penyusun KKNI Dikti, 
2013). Oleh sebab itu, keterampilan meneliti menjadi suatu hal yang harus dimiliki oleh setiap mahasiswa.

Keterampilan meneliti merupakan suatu keterampilan untuk melakukan penelitian ilmiah dalam rangka pencarian kebenaran ilmiah dengan menerapkan metode ilmiah yang bersandar pada penalaran ilmiah yang teruji (Majelis Profesor Riset Lembaga Ilmu Pengetahuan Indonesia, 2007). Melalui keterampilan ini, mahasiswa mampu membangun hubungan intelektual dan praktis yang kuat antara riset dan pembelajaran mereka sendiri (Webb, Smith, \& Worsfold, 2011). Oleh karena itu, keterampilan ini harus dimiliki mahasiswa karena mampu menjembatani mahasiswa dalam melaksanakan suatu kegiatan penelitian.

Prahmana (2015a) telah menghasilkan lintasan belajar penelitian pendidikan matematika menggunakan pembelajaran berbasis riset yang diimplementasikan terbatas kepada 14 mahasiswa Program Studi Pendidikan Matematika STKIP Surya, yang dibagi kedalam 7 kelompok penelitian. Mahasiswa memilih variabel manipulatif berupa pendekatan pembelajaran, khususnya pendekatan matematika realistik, yang menjadi salah satu tren penelitian pendidikan matematika (Sabandar, 2009).

Hasil penelitian Prahmana (2015a) menyatakan bahwa selama kurun waktu 6 bulan, seluruh kelompok penelitian menghasilkan suatu penelitian yang hasilnya dipublikasikan pada prosiding Konferensi Nasional Matematika XVII (6 karya ilmiah) dan Jurnal Elemen (1 karya ilmiah). Hal ini, membuat peneliti berani berasumsi bahwa lintasan belajar penelitian pendidikan matematika menggunakan pembelajaran berbasis riset yang dilalui mahasiswa mampu menumbuhkan keterampilan mahasiswa dalam melakukan penelitian. Selain itu, setelah proses pembelajaran, Prahmana (2015a) menemukan beberapa kekurangan dalam setiap fase yang dilalui mahasiswa untuk menumbuhkan keterampilan meneliti melalui lintasan belajar yang telah di desain menggunakan model pembelajaran berbasis riset, seperti konsep metodologi yang benar, pembuatan desain pembelajaran dan instrumen penelitian, proses implementasi desain pembelajaran, pengolahan data penelitian, dan terakhir menulis artikel ilmiah. Temuan ini menjadi dasar untuk merevisi lintasan belajar siswa sebelum diujicobakan kembali pada fase berikutnya. Selain itu, banyak penelitian yang telah mendokumentasikan keberhasilan pembelajaran berbasis riset untuk menumbuhkan keterampilan mahasiswa dalam melakukan penelitian, namun sebahagian besar dari mereka 
masih terfokus kepada mahasiswa yang berasal dari non pendidikan (Widayati dkk., 2010; Waris, 2009; Umar, Yusuf, Supartin, Uloli, Abjul, \& Ntobuo, 2011; Webb, Smith, \& Worsfold, 2011; University of Adelaide, 2009).

Berdasarkan uraian di atas, peneliti terdorong untuk mengembangkan lintasan belajar penelitian pendidikan matematika pada penelitian pendahuluan (Prahmana, 2015a) untuk menumbuhkan keterampilan mahasiswa calon guru matematika dalam melakukan penelitian. Selanjutnya, peneliti memformulasikan rumusan masalah pada penelitian ini, adalah sebagai berikut:

1. Bagaimana peranan model Pembelajaran Berbasis Riset dalam menumbuhkan keterampilan meneliti pada mahasiswa Program Studi Pendidikan Matematika?

2. Bagaimana lintasan belajar penelitian pendidikan matematika yang dilalui oleh mahasiswa dalam upaya menumbuhkan keterampilan meneliti mereka?

\section{B. Metode Penelitian}

Penelitian ini menggunakan metode penelitian design research, yang terdiri dari 3 tahapan yaitu preliminary design, teaching experiment, dan retrospective analysis (Gambar 1). Gravemeijer dan Eerde (2009) menyatakan bahwa design research adalah suatu metode penelitian yang bertujuan mengembangkan local instructional theory dengan kerjasama antara peneliti dan guru untuk meningkatkan kualitas pembelajaran.

Design research dianggap sebagai paradigma penelitian yang bertujuan untuk mengembangkan urutan kegiatan dan memahami sebuah pemahaman empiris tentang bagaimana suatu pembelajaran bekerja (Cobb, Stephan, McClain, \& Gravemeijer, 2001; Edelson, 2002; Gravemeijer, 2004; Research Advisory Committee, 1996; Widjaja, 2008), dalam penelitian ini dinamakan lintasan belajar. Selanjutnya Wang \& Hannafin (dalam Wijaya 2008) juga mendefinisikan design research sebagai metode yang sistematik tetapi fleksibel, yang ditujukan untuk meningkatkan praktek pengajaran melalui analisis berulang, desain berulang, dan implementasi, mengacu pada kolaborasi antara peneliti dan praktisi dengan situasi kehidupan sehari-hari, dan mengarah pada prinsip dan teori desain yang sensitif-kontekstual. 


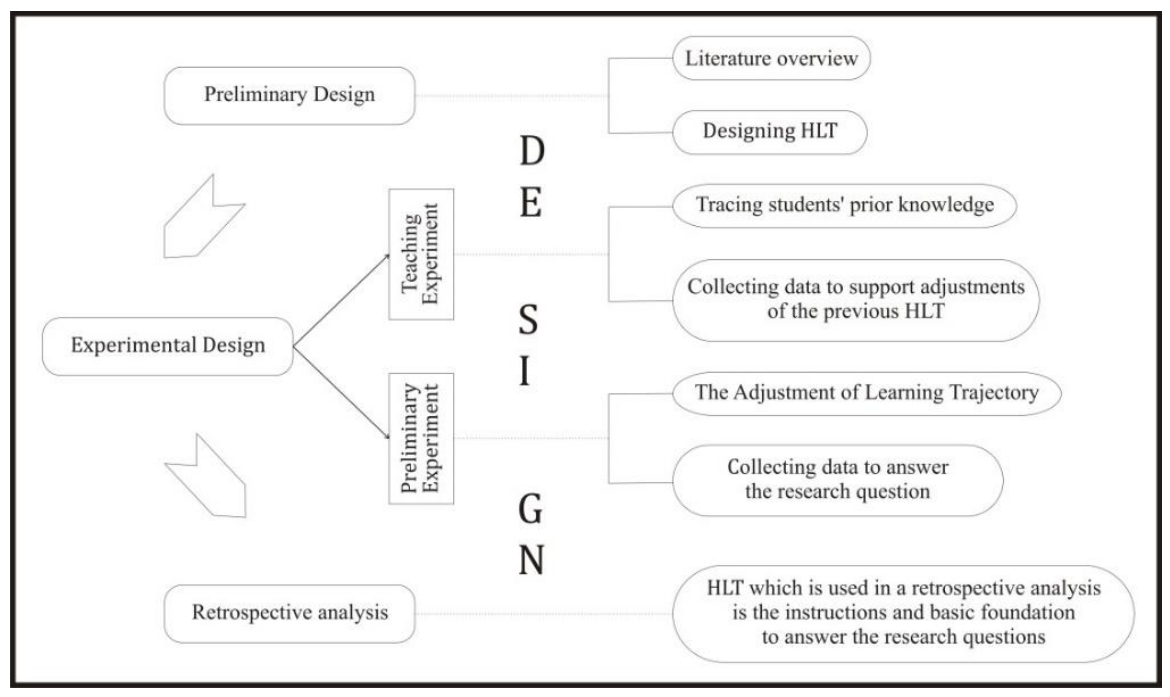

Gambar 1. Fase Penelitian Design Research (Prahmana, Zulkardi, \& Hartono, 2012)

Terdapat 2 aspek penting yang berkaitan dengan design research, yaitu Hypothetical Learning Trajectory (HLT) dan Local Instruction Theory (LIT) (Akker, Gravemeijer, McKenney, \& Nieveen, 2006). Keduanya diarahkan pada aktivitas pembelajaran sebagai jalur pembelajaran yang ditempuh oleh siswa dalam kegiatan pembelajarannya.

Peneliti telah mengumpulkan data penelitian yang berasal dari berbagai sumber data, untuk mendapatkan visualisasi terhadap proses pembelajaran berbasis riset untuk menumbuhkan keterampilan meneliti pada mahasiswa pendidikan matematika, yaitu foto kegiatan pembelajaran, penelitian, angket, portofolio mahasiswa, dan wawancara. Selanjutnya, data yang diperoleh dianalisis secara retrospektif bersama HLT sebagai pemandunya. Analisis data dilakukan oleh peneliti dan bekerja sama dengan pembimbing, serta diseminarkan untuk meningkatkan validitas dari penelitian ini. Terakhir, penelitian ini telah selesai dilakukan pada semester genap tahun akademik 2014/2015. Subjek penelitiannya adalah 9 orang mahasiswa Program Studi Pendidikan Matematika di STKIP Surya, yang terdiri dari 4 mahasiswa angkatan 2010 dan 5 mahasiswa angkatan 2011. 


\section{Temuan dan Pembahasan}

Hasil penelitian ini menunjukkan bahwa, penggunaan model pembelajaran berbasis riset dalam pendesainan pembelajaran penelitian pendidikan matematika memiliki peranan yang sangat penting sebagai tahapan pembelajaran untuk menumbuhkan keterampilan meneliti pada mahasiswa pendidikan matematika. Selama proses pembelajaran, penggunaan sintaks model pembelajaran berbasis riset, mampu memfasilitasi mahasiswa dalam menyelesaikan penelitian pendidikan matematika dan memberikan pemahaman lebih dalam konteks konten matematika yang ingin mereka gunakan dalam penelitian, dengan berbagai perlakuan untuk meningkatkan kemampuan matematis subjek penelitian mereka. Dalam hal ini, peneliti hanya bertindak sebagai fasilitator dalam proses pembelajaran dan bertindak sebagai moderator dalam proses diskusi kelas untuk mengambil sebuah kesimpulan dalam setiap proses pembelajarannya, serta sebagai validator dalam memvalidasi setiap instrument yang digunakan dalam penelitian.

Selanjutnya, lintasan belajar yang dihasilkan adalah lintasan belajar yang dilalui mahasiswa mulai dari mencari masalah penelitian, melakukan kajian literatur untuk menjawab permasalahan yang ada, membuat indikator dan desain penelitian, menentukan metode penelitian yang benar dalam menjawab rumusan masalah penelitian, memilih dan memilah data penelitian yang akan digunakan untuk menjawab masalah yang telah dirumuskan, membuat karya ilmiah sebagai bentuk laporan hasil penelitian, sampai dengan mempublikasikan hasil penelitian dalam bentuk artikel ilmiah yang dipublikasikan dalam jurnal atau skripsi yang dimuat di perpustakaan. Setelah implementasi lintasan pembelajaran yang telah di desain, hasil yang dicapai berbeda untuk setiap subjek penelitian, berdasarkan indikator keterampilan meneliti, yaitu (1) mahasiswa mampu membuat rumusan masalah; (2) mahasiswa mampu melakukan observasi untuk mencari informasi dan metodologi yang dibutuhkan (relevan); (3) mahasiswa mampu membuat rancangan penelitian; (4) mahasiswa mampu memilah dan mendeskripsikan data penelitian yang telah dikumpulkan; (5) mahasiswa mampu menganalisis data penelitian untuk menjawab rumusan masalah dan kemudian 
menginterpretasikannya, serta membuat kesimpulan; dan (6) mahasiswa mampu mengkomunikasikan hasil penelitiannya, baik dalam bentuk diseminasi pada forum ilmiah maupun publikasi ilmiah dalam bentuk jurnal atau prosiding (Prahmana, 2015b). Berdasarkan semua aktivitas yang dilalui mahasiswa, peneliti dapat menyatakan bahwa lintasan belajar yang telah di desain mampu menumbuhkan keterampilan mahasiswa dalam melakukan penelitian.

Untuk lebih jelasnya, peneliti membahas seluruh proses jalannya pembelajaran penelitian pendidikan matematika menggunakan model pembelajaran berbasis riset, kedalam 3 tahapan, yaitu preliminary design, teaching experiment, dan Analisis Retrospektif. Semua tahapan tersebut merupakan hasil dan pembahasan dalam bagian ini.

\section{Preliminary Design (Desain Pendahuluan)}

Pada tahapan ini, peneliti mengimplementasikan ide awal tentang penggunaan model pembelajaran berbasis riset dalam mendesain lintasan belajar penelitian pendidikan matematika dengan mengkaji literature, melakukan observasi awal ke mahasiswa mengenai ide penelitian yang mereka lakukan, dan diakhiri dengan mendesain hypothetical learning trajectory (HLT), seperti tampak pada Gambar 2.

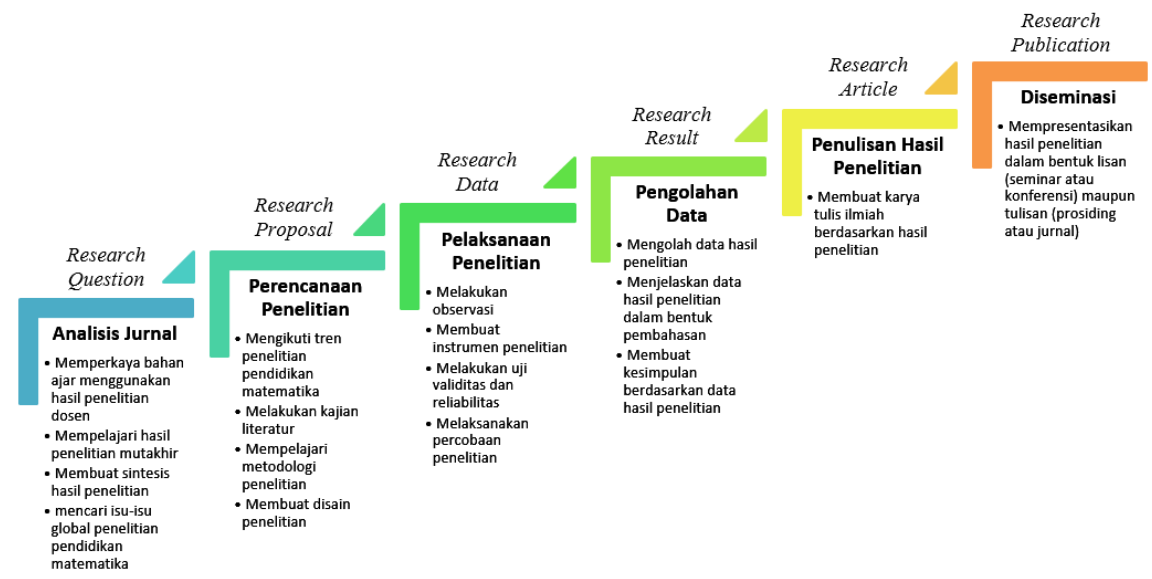

Gambar 2. Learning Trajectory Penelitian Pendidikan Matematika

Sekumpulan aktivitas pembelajaran dalam penelitian pendidikan matematika untuk menumbuhkan keterampilan mahasiswa dalam melakukan penelitian telah di desain berdasarkan sintaks model pembelajaran berbasis riset, tahapan penelitian pendidikan matematika 
berdasarkan indikator keterampilan meneliti yang ingin ditumbuhkan, dan proses berfikir mahasiswa yang telah dihipotesakan. Himpunan aktivitas instruksi ini telah dibagi kedalam 6 aktivitas yang telah diselesaikan dalam kurun waktu 5 bulan pembelajaran, dengan intensitas pertemuan 1-2 kali pertemuan setiap minggu, mulai dari mencari masalah penelitian, menentukan topik penelitian beserta metode penelitian yang mampu menyelesaikannya, melakukan pengambilan data penelitian, penulisan hasil penelitian, mempublikasikan hasil penelitian dalam bentuk artikel ilmiah di jurnal atau skripsi, sampai dengan proses evaluasi dalam bentuk seminar proposal atau seminar skripsi.

Selanjutnya, penelitian ini dimaksudkan untuk menumbuhkan keterampilan mahasiswa dalam melakukan penelitian, dalam upaya memfasilitasi mahasiswa dalam pembuatan proposal penelitian dan skripsi, serta artikel ilmiah yang dipublikasikan dalam jurnal, sebagai bagian dari pemenuhan standar kompetensi lulusan S1, berdasarkan Kerangka Kualifikasi Nasional Indonesia (KKNI) dan surat edaran Dikti tentang publikasi ilmiah. Selain itu, berdasarkan hasil observasi awal, ditemukan bahwa sebahagian besar mahasiswa ingin melakukan penelitian eksperimen, maka peneliti juga mendesain lintasan pembelajaran untuk penelitian eksperimen (Gambar 3).
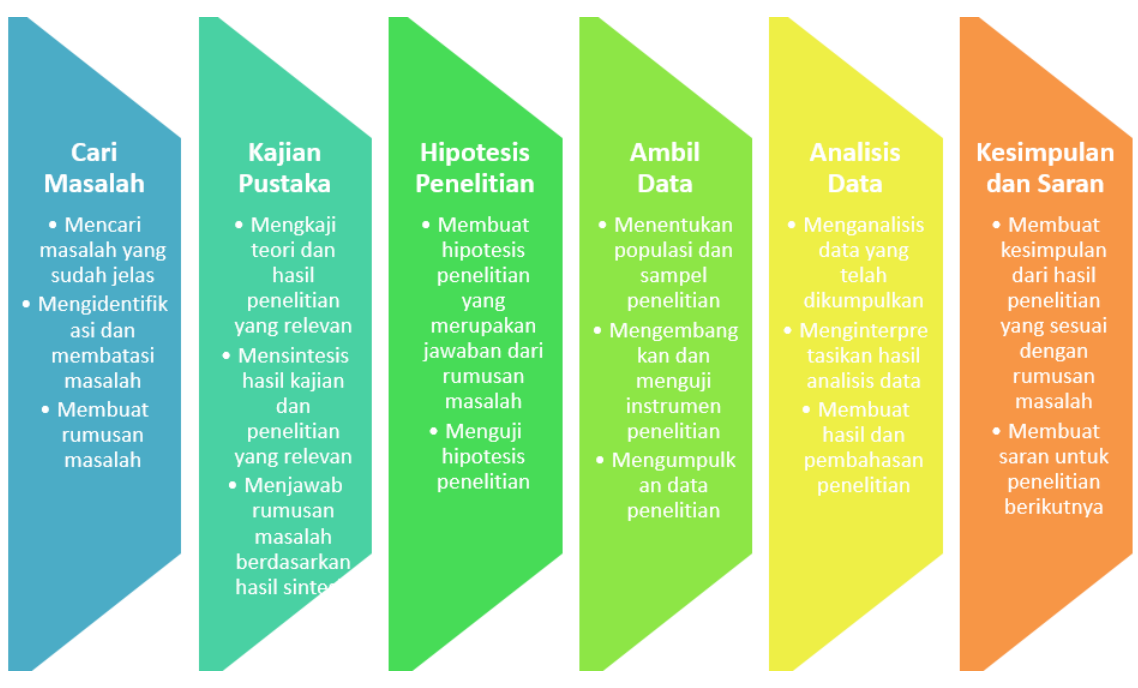

Gambar 3. Lintasan Belajar Penelitian Eksperimen 


\section{Teaching Experiment}

Pada tahapan ini, peneliti mengujicobakan aktivitas pembelajaran yang telah didesain pada tahap preliminary design, yaitu aktivitas yang di desain berdasarkan sintaks model pembelajaran berbasis riset dan disesuaikan dengan kompetensi dasar mata kuliah seminar proposal dan skripsi, serta indikator keterampilan meneliti. Proses pembelajaran dimulai dengan mencari masalah yang diteliti berdasarkan kajian literature dari hasil penelitian sebelumnya dan hasil observasi di beberapa kelas tempat mahasiswa melakukan penelitian. Selanjutnya, mahasiswa melakukan kajian literature untuk mencari jawaban atas masalah yang telah ditemukan. Berdasarkan hasil kajian tersebut, mahasiswa membuat hipotesis yang merupakan jawaban sementara dari permasalahan yang telah dirumuskan. Kemudian, mahasiswa membuat instrument penelitian untuk mengumpulkan data pendukung dan melakukan analisis data sebagai bagian dari uji hipotesis penelitian. Terakhir, mahasiswa menginterpretasikan hasil analisis data dalam bentuk karya ilmiah dan mempublikasikannya. Selama proses pembelajaran, dosen bertindak sebagai fasilitator dan validator mahasiswa dalam melakukan penelitian.

\section{Analisis Retrospektif}

Model pembelajaran berbasis riset memiliki sintaks yang merupakan tahapan-tahapan yang harus dilalui mahasiswa selama proses pembelajaran. Tahapan-tahapan tersebut telah dimodifikasi dan disesuaikan dengan pembelajaran matematika untuk menumbuhkan keterampilan meneliti (disesuaikan dengan indikator keterampilan). Akibatnya, proses dalam pembelajaran tersebut dapat dijadikan alasan menarik untuk menjawab research question pertama berikut ini.

Bagaimana peranan model Pembelajaran Berbasis Riset dalam menumbuhkan keterampilan meneliti pada mahasiswa Program Studi Pendidikan Matematika?

Tahapan pembelajaran yang dilalui mahasiswa untuk menumbuhkan keterampilan meneliti digunakan dalam menjawab research question di atas. Pencapaian mahasiswa dalam memenuhi semua indikator keterampilan meneliti (Prahmana, 2015b) dijelaskan sebagai berikut. 
1. Mahasiswa mampu membuat rumusan masalah, melakukan observasi untuk mencari informasi, dan metodologi yang relevan.

Seluruh subjek penelitian yang terdiri dari 4 mahasiswa semester 8 dan 5 mahasiswa semester 6 Program Studi Pendidikan Matematika telah mampu membuat rumusan masalah penelitian dan melakukan observasi awal untuk mencari informasi dan metodologi yang relevan. Seluruh subjek penelitian memilih penelitian kuantitatif untuk menjawab rumusan masalah yang dikemukakan. Sedangkan untuk topik penelitian, 2 mahasiswa membahas tentang Matematika GASING, 5 mahasiswa membahas tentang Pendidikan Matematika Realistik, 1 mahasiswa membahas tentang Kecemasan Matematika, dan 1 mahasiswa membahas tentang Kemampuan Reversibilitas.

2. Mahasiswa mampu membuat rancangan penelitian, serta memilah, dan mendeskripsikan data penelitian yang telah dikumpulkan.

Sebanyak 8 mahasiswa telah mampu membuat rancangan penelitian dan 1 mahasiswa masih dalam proses pembuatan rancangan penelitian. Kesulitan yang dihadapi mahasiswa dalam pembuatan rancangan penelitian, lebih dikarenakan rendahnya kemampuan literasi mahasiswa dalam menganalisis jurnal hasil penelitian sebelumnya. Sedangkan, kemampuan mahasiswa dalam memilah dan mendeskripsikan data penelitian yang telah dikumpulkan, masih belum maksimal, dikarenakan mahasiswa masih terfokus untuk memperbaiki dan menyempurnakan desain dan instrument penelitian. Indikator ini baru dipenuhi oleh 3 dari 9 subjek penelitian, memiliki waktu lebih lama dalam proses penelitian.

3. Mahasiswa mampu menganalisis data penelitian untuk menjawab rumusan masalah dan kemudian menginterpretasikannya, serta membuat kesimpulan.

Indikator ini baru dipenuhi oleh 3 mahasiswa semester 8 (33\%). Hasil analisis data penelitian untuk menjawab rumusan masalah dan kemudian menginterpretasikannya, serta membuat 
kesimpulan, dari tiap mahasiswa berbeda antara satu dengan yang lainnya. Hal ini dikarenakan 1 mahasiswa menggunakan 2 kelas penelitian (eksperimen dan kontrol) untuk melihat pengaruh dan 2 mahasiswa hanya menggunakan 1 kelas untuk melihat peningkatan. Secara keseluruhan, ketiga mahasiswa mampu memenuhi indikator ini, selain difasilitasi oleh dosen, juga karena adanya sistem belajar bersama, seperti tutor sebaya. Seluruh subjek penelitian mampu saling membantu dan belajar bersama, dikarenakan mereka tinggal dalam sistem asrama.

4. Mahasiswa mampu mengkomunikasikan hasil penelitiannya, baik dalam bentuk diseminasi pada forum ilmiah maupun publikasi ilmiah dalam bentuk jurnal atau prosiding.

Bentuk komunikasi hasil penelitian dibagi menjadi 2 tahapan, yaitu seminar hasil penelitian (skripsi) dan publikasi artikel ilmiah pada jurnal atau prosiding. Mahasiswa yang mampu sampai tahapan seminar hasil penelitian (skripsi) berjumlah 3 orang dan publikasi artikel ilmiah pada jurnal nasional ber-ISSN ter-Indeks Google Scholar berjumlah 2 orang. Berdasarkan hasil wawancara diketahui bahwa kesulitan terbesar dalam mempublikasikan hasil penelitian pada jurnal terletak pada kurangnya informasi tentang bagaimana mempublikasikan hasil penelitian dan dosen pembimbing memberikan pengaruh yang signifikan dalam hal ini.

Pada research question kedua, peneliti lebih memfokuskan pada proses tumbuhnya keterampilan mahasiswa dalam melakukan penelitian dalam lintasan belajar yang telah di desain (Gambar 2), mulai dari aktivitas mencari masalah, observasi, mendesain penelitian dan instrument penelitian, mengumpulkan dan menginterpretasikan data penelitian, membuat kesimpulan, sampai dengan mengkomunikasikan hasil penelitian, sebagaimana pernyataan dalam research question kedua berikut ini.

Bagaimana lintasan belajar penelitian pendidikan matematika yang dilalui oleh mahasiswa dalam upaya menumbuhkan keterampilan meneliti mereka? 
Bentuk lintasan yang telah dimodelkan dapat dijadikan landasan atau pedoman dalam menjawab research question kedua di atas. Aktivitas dalam penelitian ini memunculkan lintasan belajar penelitian pendidikan matematika, yang dibagi menjadi 6 tahapan. Tahapan pertama dinamakan research question, yang terdiri dari aktivitas analisis jurnal, seperti mempelajari hasil penelitian terbaru, membuat sintesis, dan mencari isuisu global penelitian pendidikan matematika, agar mahasiswa mampu membuat rumusan masalah penelitian. Tahapan kedua diberi nama research proposal, yang terdiri dari perencanaan penelitian, seperti mengikuti tren penelitian pendidikan matematika, melakukan kajian literature, mempelajari metodologi penelitian dan membuat desain penelitian, agar mahasiswa memiliki dasar pengetahuan tentang metodologi penelitian yang benar dan memiliki wawasan yang luas tentang penelitian pendidikan matematika. Tahapan ketiga dinamakan research data, yang merupakan proses pelaksanaan penelitian, seperti melakukan observasi, membuat instrument penelitian, melakukan uji validitas dan reliabilitas instrument, serta melaksanakan percobaan penelitian, agar mahasiwa mampu melakukan observasi dan penelitian awal untuk mendapatkan data awal sehingga mampu memilih metode penelitian dan mendesain penelitian yang tepat. Tahapan selanjutnya dinamakan research result, yang merupakan proses pengolahan data penelitian, agar mahasiswa mampu mengumpulkan, memilah, dan mendeskripsikan data penelitian yang telah dikumpulkan. Selanjutnya, melalui tahapan ini, mahasiswa mampu menganalisis data penelitian untuk menjawab rumusan masalah dan kemudian menginterpretasikannya, serta membuat kesimpulan penelitian. Tahapan kelima dinamakan result article, yang merupakan proses penulisan hasil penelitian dalam bentuk karya ilmiah (skripsi atau artikel ilmiah), agar mahasiswa mampu menuliskan hasil penelitiannya.

Proses penulisan hasil penelitian menjadi permasalahan tersendiri bagi setiap mahasiswa (Rahmiati, 2014). Tahapan terakhir dinamakan research publication, yang merupakan proses diseminasi, yaitu mengkomunikasikan hasil penelitiannya, agar mahasiswa mampu mempresentasikan hasil penelitiannya pada seminar hasi penelitian (skripsi) dan publikasi hasil penelitian dalam jurnal. Seluruh tahapan ini, mampu menumbuhkan keterampilan mahasiswa dalam melakukan penelitian. 


\section{Simpulan}

Berdasarkan hasil penelitian dan pembahasan yang telah diuraikan pada bagian sebelumnya, peneliti dapat menyimpulkan bahwa sintaks model pembelajaran berbasis riset memiliki peran yang besar dalam menumbuhkan keterampilan meneliti. Selanjutnya, lintasan belajar yang dihasilkan adalah lintasan belajar yang dilalui mahasiswa dalam upaya menumbuhkan keterampilan mahasiswa dalam melakukan penelitian pendidikan matematika. Seluruh indikator keterampilan meneliti dipenuhi melalui tahapan yang telah di desain.

\section{Daftar Pustaka}

Akker, Jvd, Gravemeijer, K., McKenney, S., \& Nieveen. (2006). Educational design research. London: Routledge Taylor and Francis Group.

Bangun, P.B.J., Irmeilyana, \& Andarini, I. (2011). Analisis korespondensi untuk mengetahui hubungan lama studi dengan IPK dan lama skripsi alumni matematika FMIPA UNSRI Angkatan 2001-2002. Jurnal Penelitian Sains, 14 (1(A)), 13-18.

Cobb, P., Stephan, M., McClain, K., \& Gravemeijer, K. (2001). Participating in classroom mathematical practices. The Journal of the Learning Sciences, 10 (1\&2), 113-163.

Edelson, D.C. (2002). Design research: What we learn when we engage in design. The Journal of the Learning Sciences, 11 (1), 105-121.

Fathonah, S., Wahyuningsih, S.E., \& Wahyuningsih, U. (2011). Determinan masa penulisan skripsi mahasiswa prodi PKK. Jurnal Kompetensi Teknik, 2 (2), 127-136.

Firmansyah, R. (2014). Kecemasan mahasiswa dalam menyelesaikan tugas akhir studi dan solusinya perspektif bimbingan dan konseling Islami. Skripsi. Semarang: Institut Agama Islam Negeri Walisongo. Retrieved from http://eprints.walisongo.ac.id/2570/.

Gravemeijer, K. \& Van Eerde, D. (2009). Design research as a means for building a knowledge base for teaching in mathematics education. The Elementary School Journal, 109 (5), 510-524.

Gravemeijer, K. (2004). Local instructional theories as means of support for teacher in reform mathematics education. Mathematical Thinking and Learning, 6 (2), 105-128.

Majelis Profesor Riset Lembaga Ilmu Pengetahuan Indonesia. (2007). Kode etika peneliti. Jakarta: Lembaga IImu Pengetahuan Indonesia.

Prahmana, R.C.I. (2014). Faktor penyebab kesulitan mahasiswa dalam penulisan proposal skripsi. Observation Report. Tangerang: STKIP Surya.

Prahmana, R.C.I. (2015a). The hypothetical learning trajectory on research in mathematics education using research-based learning. Makalah yang 
dipresentasikan dalam kegiatan The Third South East Asia Design/Development Research (SEA-DR) International Conference 2015. Palembang: Universitas Sriwijaya.

Prahmana, R.C.I. (2015b). Penelitian pendidikan matematika. Yogyakarta: Matematika.

Prahmana, R.C.I., Zulkardi, \& Hartono, Y. (2012). Learning multiplication using Indonesian traditional game in third grade. Journal on Mathematics Education, 3 (2), 115-132.

Puspitasari, R.T. (2013). Adversity quotient dengan kecemasan mengerjakan skripsi pada mahasiswa. Jurnal Online Psikologi, 1 (2), 299-310.

Rahmiati. (2014). Problematika mahasiswa dalam menulis karya ilmiah. Jurnal Al Hikmah, 14 (1), 90-106.

Research Advisory Committee. (1996). Justification and reform. Journal for Research in Mathematics Education, 27 (5), 516-520.

Sabandar, J. (2009). Tren Penelitian Pendidikan Matematika. Makalah UPI. Bandung: Sekolah Pascasarjana, Universitas Pendidikan Indonesia.

Santosa, A.B., Wiyanarti, M., \& Darmawan, W. (2009). Peran team pertimbangan penulisan skripsi: benarkah sudah optimal? Jurnal Penelitian, 10(2), 1-7.

Siswono, T.Y.E. (2010). Penelitian pendidikan matematika. Surabaya: Unesa University Press.

Tim Penyusun KKNI Dikti. (2013). Kerangka kualifikasi nasional Indonesia dan implikasinya pada dunia kerja dan pendidikan tinggi. Jakarta: Dikti.

Umar, M.K., Yusuf, M. Supartin, Uloli, R. Abjul, T., \& Ntobuo, N.E. (2011). Laporan hasil penelitian pengembangan pembelajaran berbasis riset di Program Studi Pendidikan Fisika FMIPA Universitas Negeri Gorontalo. Gorontalo: Universitas Negeri Gorontalo.

University of Adelaide. (2009). A Handbook for research skill development and assessment in the curriculum. Adelaide: the Australian Learning and Teaching Council Ltd.

Waris, A. (2009). Model pembelajaran berbasis riset (PBR) di Program Studi Fisika ITB. Berita Pembelajaran, 6 (2), 1-3.

Webb, F., Smith, C., \& Worsfold, K. (2011). Research skills toolkit. Queensland: Griffith Institute for Higher Education.

Widayati, D.T., Luknanto, D., Rahayuningsih, E., Sutapa, G., Harsono, Sancayaningsing, R.P., \& Sajarwa. (2010). Pedoman umum pembelajaran berbasis riset. Yogyakarta: Universitas Gadjah Mada.

Widjaja, W. (2008). Local instruction theory on decimals: The case of indonesian pre-service teachers. Disertasi. Melbourne: Melbourne Graduate School of Education, the University of Melbourne.

Willison, J., \& O'Regan, K. (2007). Commonly known, commonly not known, totally unknown: a framework for students becoming researchers. The Higher Education Research and Development, 26(4), 393-409. 